\title{
Analisis Kelayakan Investasi Perkebunan Rambutan di Desa Jungkal Kecamatan Lampihong Kabupaten Balangan
}

\section{(Analysis Feasibility of Investments Rambutan Plantation in Jungkal Village Lampihong District Balangan Regency)}

\author{
Miranda Romaully Br. Sitanggang ${ }^{1)}$ \& Norhalimah ${ }^{2)}$ \\ Program Studi Agribisnis, Sekolah Tinggi Ilmu Pertanian Amuntai \\ ${ }^{1)}$ miranda.rsd2203@gmail.com \\ ${ }^{2}$ halimahnor@gmail.com
}

\begin{abstract}
ABSTRAK
Penelitian ini bertujuan mengetahui kelayakan investasi perkebunan rambutan di Desa Jungkal Kecamatan Lampihong Kabupaten Balangan dilihat dari non finansial yaitu aspek pasar, aspek teknis, aspek manajemen, dan aspek finansial. Penelitian dilakukan di Desa Jungkal, Kecamatan Lampihong. Metode penelitian yang digunakan adalah metode sensus dimana sebanyak 20 pemilik usaha kebun rambutan dijadikan responden. Pengumpulan data dilakukan dari Mei - Agustus 2014. Analisis aspek finansial menggunakan kriteria investasi yang terdiri dari Net Present Value (NPV), Internal Rate of Return (IRR), Net Benefit Cost Rasio (Net B/C), dan payback period. Hasil penelitian yang diperoleh dari aspek non finansial menunjukan bahwa investasi usaha perkebunan rambutan layak dilakukan, ditunjukkan potensi pasar yang cukup tinggi, lokasi usaha perkebunan yang menunjang keberhasilan usaha, dan rencana kerja dalam menajemennya dapat dilakukan dengan memperhatikan kondisi yang ada. Dari asfek finansial investasi usaha perkebunan rambutan di Desa Jungkal layak dilakukan ditunjukan oleh Net Present Vlue (NPV) sebesar Rp134.646.379, -, nilai Internal Rate of Return (IRR) yang dihasilkan lebih besar dari tingkat discount rate yaitu sebesar 30.01\%. Net B / C sebesar 4.50, dan payback period selama 8 tahun 11 bulan 26 hari, ini menunjukkan bahwa secara finansial investasi usaha perkebunan rambutan layak untuk dilakukan.
\end{abstract}

Kata Kunci : Analisis, kelayakan, investasi, perkebunan, rambutan.

\section{ABSTRACT}

This study aims to determine the feasibility of rambutan plantation investment in Jungkal Village, Lampihong Subdistrict, Balangan Regency, seen from non-financial aspects, namely market aspects, technical aspects, management aspects, and financial aspects. The study was conducted in Jungkal Village, Lampihong District. The research method used was the census method where as many as 20 rambutan garden business owners were made respondents. Data collection was conducted from May August 2014. Analysis of financial aspects used investment criteria consisting of Net Present Value $(N P V)$, Internal Rate of Return (IRR), Net Benefit Cost Ratio (Net B / C), and payback period. The results of research obtained from non-financial aspects show that the investment in rambutan plantation is feasible, it is shown that the market potential is quite high, the location of the plantation business that supports the success of the business, and the work plan in its management can be done by taking into account existing conditions. From the financial aspects of the rambutan plantation business investment in Jungkal Village, it is feasible to show the Net Present Vlue (NPV) of Rp134,646,379, - the value of the Internal Rate of Return (IRR) is greater than the discount rate of 30.01\%. Net B / C is 4.50, and the payback period is 8 years 11 months 26 days, this shows that financially the investment in rambutan plantation is feasible.

Keywords: Analysis, feasibility, investment, rambutan, plantation.

\section{PENDAHULUAN}

Sektor pertanian merupakan salah satu sektor yang memberikan kontribusi yang sangat besar dalam perekonomian nasional. Subsektor usaha tanaman hortikultura termasuk salah satu subsektor yang memegang peranan penting dalam sektor pertanian. Hortikultura merupakan salah satu komoditas yang mempunyai potensi besar untuk dikembangkan diantara berbagai komoditas pertanian yang ada di Indonesia. 
Ketersediaan beragam jenis tanaman hortikultura yang meliputi tanaman sayur, buah, tanaman hias, dan tanaman obat yang dimiliki Indonesia dapat menjadi kegiatan usaha ekonomi yang sangat menguntungkan apabila dapat dikelola secara optimal (Ditjen Hortikultura, 2013).

Daerah-daerah yang mempunyai potensi sumber daya pertanian dapat memprioritaskan pengembangan agribisnis buah-buahan sebagai salah satu basis ekonomi daerah. Selain itu, pembangunan wilayah pertanian di daerah juga bertujuan untuk mengembangkan dan menghasilkan komoditas unggulan pertanian.

Rambutan di Indonesia merupakan produk hortikultura yang mempunyai potensi besar dipasar lokal maupun ekspor,yang ditunjukkan dengan permintaannyayang cukupbesar. Tanaman rambutan merupakan salah satu tanaman yang mempunyai prospek agribisnis yang cerah di masa yang akan datang. Tanaman rambutan asal Indonesia telah menembus pasar internasional, seperti Inggris, belanda, Perancis, Belgia, dan Negara-negara di Asia Barat, dan Asia Tenggara (Soedarya, 2009).

Berkebun rambutan merupakan salah satu jenis usaha yang dilakukan petani di Desa Jungkal Kecamatan Lampihong secara turun-temurun. Berkebun Rambutan di Desa Jungkal mempunyai beberapa potensi pengembangan wilayah yang cukup luas dengan didukung oleh iklim dan kondisi tanah yang menunjang bagi pertumbuhan tanaman rambutan serta produktivitas buah rambutan.

Menanamkan investasi atau penanaman modal dalam suatu usaha perkebunan rambutan memerlukan studi yang serius terhadap kelayakan dan prospek usaha di masa depan. Tanpa perencanaan dan kajian (studi) kelayakan yang mendalam, maka suatu usaha atau investasi dapat dipastikan akan sia-sia atau merugi. Padahal salah satu tujuan didirikannya usaha ialah untuk mencari keuntungan (profit (Kasmir dan Jakfar. 2004).

Rambutan sebagai usaha yang telah lama dilakukan, dan berdasarkan potensi dan permasalahan yang ada, maka dipandang perlu untuk melakukan analisis kelayakan investasi perkebunan rambutan di Desa Jungkal Kecamatan Lampihong. Analisis kelayakan ini penting untuk dilakukan karena dengan analisis kelayakan bertujuan untuk menilai apakah usaha ini layak diusahakan atau sebaliknya tidak layak diusahakan. Untuk menilai kelayakan diperlukan penilaian terhadap aspek pasar, aspek teknis, dan aspek manajemen serta aspek finansialnya.

Tujuan penelitian ini adalah (i) mengetahui kelayakan investasi perkebunan rambutan dilihat dari aspek non finansial yaitu aspek pasar, aspek teknis, dan aspek manajemen (ii) mengetahui kelayakan investasi perkebunan rambutan dilihat dari aspek finansial.

\section{METODE PENELITIAN}

\section{Tempat dan Waktu Penelitian}

Penelitian ini dilakukan di Desa Jungkal Kecamatan Lampihong Kabupaten Balangan, pada bulan Mei - Agustus 2014 mulai dai tahap persiapan, pengumpulan data, sampai dengan penyusunan laporan.

\section{Jenis dan Sumber Data}

Jenis dan sumber data yang digunakan dalam penelitian ini adalah data sekunder dan data primer. Data primer berasal dari wawancara langsung kepada responden dengan menggunakan daftar pertanyaan yang sudah disiapkan sebagai panduan dalam menjawab penelitian. Data sekunder yang digunakan dalam penelitian ini diperoleh dari studi literatur berbagai buku, skripsi, internet, dan instansi-instansi terkait.

\section{Metode Pengumpulan Data}

Metode pengumpulan data yang digunakan adalah metode sensus dimana 20 responden dijadikan sampel. Teknik pengumpulan data yang dilakukan adalah dengan cara wawancara langsung. Responden yang diwawancara adalah pemilik usaha kebun rambutan.

\section{Analisis Data}

Analisis data untuk menjawab tujuan yang pertama, dilakukan analisis pada aspek-aspek non finansial yaitu aspek pasar, aspek teknis dan aspek manajemen dengan menggunakan metode dekriptif. 
Menjawab tujuan yang kedua dilakukan analisis pada aspek finansial. Kriteria investasi yang digunakan adalah Net Present Value (NPV), Internal Rate of Return (IRR), Net Benefit Cost Rasio (Net $\mathrm{B} / \mathrm{C})$, dan payback period.

\section{HASIL DAN PEMBAHASAN}

\section{Hasil}

\section{Analisis Aspek Non Finansial}

Analisis aspek-aspek non finansial dalam penelitian ini dilihat dari aspek pasar, aspek teknis dan aspek manajemen.

\section{Aspek Pasar}

Potensi pasar buah rambutan terlihat dari jumlah permintaan yang tetap tinggi dan diproyeksikan cenderung mengalami peningkatan. Hal ini terjadi akibat kesadaran gizi masyarakat, pendidikan, dan kemampuan daya beli masyarakat. Lokasi pemasaran buah rambutan yaitu Lampihong, Amuntai, Tanjung, Barabai, dan Samarinda.

Diproyeksikan untuk penawaran dimasa yang akan datang akan berkurang, dikarenakan saat ini untuk produsen rambutan terutama yang ada di Kabupaten Balangan dan diperkirakan juga untuk daerah lainnya seperti Tanjung dan Barabai produksi rambutan cenderung berkurang karena kebun rambutan yang sudah ada telah lama dan produksi sudah berkurang serta beberapa kebun rambutan telah diganti dengan kebun karet dan tanaman semusim lainnya. Saat ini sangat jarang ada petani yang membuka kebun/perkebunan rambutan baru dan ini merupakan peluang bagi investor yang ingin mengusahakan perkebunan rambutan.

Dalam strategi pemasaran terdapat strategi bauran pemasaran (marketing mix) yaitu strategi produk, strategi harga, strategi lokasi, dan strategi promosi.

a. Strategi Produk

Produk yang dihasilkan pada perkebunan rambutan umumnya adalah buah rambutansegar. Buah rambutan dipasarkan dalam bentuk segar 10-12 butir buah rambutan perikat. Pengikatan buah rambutan 12 butir perikat dilakukan agar jika terjadi kerontokan buah yang telah diikat (1-2 butir buah rambutan), jumlah buah rambutan tidak kurang dari 10 butir perikat. Selain dipasarkan dalam bentuk buah segar, buah rambutan juga bisa dipasarkan dalam bentuk buah olahan seperti menjadi manisan, jus, selai, dan buah dalam sirup.

\section{b. Strategi Harga}

Harga rata-rata buah rambutan untuk wilayah Kabupaten Balangan, Hulu Sungai Utara, dan Tabalong adalah $\mathrm{Rp}$ 2.000,/perikat dan untuk wilayah Samarinda adalah Rp 4.000,-/perikat. Dan diproyeksikan harga cenderung meningkat seiring terjadinya inflasi.

c. Strategi lokasi

Lokasi pemasaran buah rambutan segar berdasarkan produksi yang dihasilkan dibedakan menjadi dua bagian. Ketika produksi yang dihasilkan sedikit wilayah pemasaran adalah daerah sekitar, Pasar Amuntai, Lampihong, Balangan, dan Tanjung. Sedangkan pada saat produksi yang dihasilkan banyak wilayah pemasaran adalah Kota Samarinda yaitu pasar Pagi, Sagiri, dan Balimbing. Selain wilayah tersebut, pemasaran buah rambutan dapat menjalin kerjasama dengan industri makanan dan minuman, serta ekspor.

d. Strategi Promosi

Promosi yang dilakukan dalam pemasaran buah rambutan adalah dengan memperkenalkan produk kepada rekanrekan, konsumen, industri pengolahan makanan dan minuman, serta dunia maya melalui internet.

Berdasarkan aspek pasar tersebut dapat disimpulkan bahwa diperkirakan usaha investasi perkebunan rambutan layak diusahakan, karena potensi pasar yang cukup tinggi.

\section{Aspek teknis}

1. Lokasi usaha

Lokasi usaha perkebunan rambutan terletak di lahan tegal Desa Jungkal RT. 04 Kecamatan Lampihong Kabupaten Balangan. Lokasi ini menguntungkan karena tanaman rambutan dapat tumbuh dengan baik di lahan tersebut berdasarkan analisis pada tanaman rambutan yang pernah 
dibudidayakan petani sebelumnya. Lokasi perkebunan dekat dengan air, dekat dengan petani atau penggarap. Lokasi perkebunan dekat dengan jalan pertanian sehingga mudah dalam pengangkutan input produksi dan hasil perkebunan.

Lahan yang dibeli untuk perkebunan rambutan adalah lahan kosong atau tanaman yang ada di lahan tersebut bukan tanaman yang bernilai mahal seperti lahan karet unggul, sehingga harganya lebih murah. Luas lahan untuk lokasi perkebunan rambutan dalam usaha ini diperkirakan $1 \mathrm{Ha}$ dengan proyeksi harga sekitar Rp 30.000.000,-.

2. Input produksi

Input utama perkebunan rambutan adalah bibit rambutan dan pupuk. Bibit rambutan yang digunakan adalah jenis antalagi dan sibatuk ganal. Pemilihan jenis bibit ini dikarenakan banyak konsumen yang menyukai jenis rambutan ini. Bibit dan pupuk tersebut dapat dibeli di pasar Paringin Kabupaten Balangan. Dan pupuk kandang dapat dibeli pada warga sekitar yang memiliki usaha peternakan ayam potong.
Mengingat di Desa Jungkal banyak warga yang memiliki usaha peternakan ayam potong dan mereka menjual pupuk kandang dari kotoran ayam tersebut.

3. Luas produksi

Luas produksi perkebunan rambutan 1 Ha dengan populasi tanaman 100 pohon.

4. Proses produksi

Proses produksi/budidaya rambutan meliputi kegiatan-kegiatan pokok penyiapan bibit dan lahan, penanaman, dan pemeliharaan tanaman, serta panen dan penanganan pascapanen.

Berdasarkan aspek teknis tersebut dapat disimpulkan bahwa diperkirakan usaha investasi perkebunan rambutan layak diusahakan. Hal ini karena lokasi usaha perkebunan yang menunjang keberhasilan usaha dilihat dari kecocokan lahan dengan tanaman rambutan, kedekatan dengan bahan baku dan para pekerja, serta mudahnya transportasi.

\section{Aspek Manajemen}

Rencana kerja perkebunan rambutan dapat dilihat pada tabel berikut

Tabel 1. Rencana kerja perkebunan rambutan

\begin{tabular}{ccc}
\hline No & Jenis pekerjaan & Waktu \\
\hline 1 & Penyiapan lahan & 1,5 bulan \\
2 & Pembuatan bangunan dan sumur & $3-6$ hari \\
3 & Pembuatan lubang tanam & $1-2$ hari \\
4 & Penanaman & $1-2$ hari \\
5 & Pemeliharaan & Selama perkebunan \\
\hline
\end{tabular}

Mereka yang terlibat adalah seluruh tenaga kerja. Penyiapan lahan dilakukan oleh petani atau tenaga kerja, dan lahan tersebut akan siap digunakan setelah 1, 5 bulan. Pembuatan bangunan dan sumur akan selesai dalam 3-6 hari. Sedangkan pembuatan lubang tanam selesai dalam 1-2 hari. Penanaman bibit rambutan dilakukan 1 minggu setelah pembuatan lubang tanam, juga selesai dalam 1-2 hari. Seluruh pelaksanaan diatur dan diawasi dengan melihat langsung hasil kerja para tenaga kerja.

Untuk panen dan perlakuan setelah panen kebutuhan tenaga kerja tergantung dari jumlah produksi buah rambutan yang dipanen. Pemasaran hanya dilakukan di daerah sekitar jika jumlah produksi sedikit. Sedangkan jika jumlah produksi banyak wilayah pemasaran cukup jauh yaitu samarinda. Perbedaan ini berdasarkan pertimbangan agar didapat keuntungan yang optimal (perbandingan biaya, tenaga kerja, dan keuntungan). Jika hasil produksi yang dijual sedikit dan wilayah pemasaran jauh walaupun harga lebih mahal maka tetap rugi karena lebih tinggi penambahan biaya transportasi daripada penambahan pendapatan. Sebaliknya jika hasil produksi yang dijual banyak dan wilayah pemasaran jauh maka akan terjadi penambahan keuntungan karena harga lebih tinggi dan 
penambahan biaya transportasi lebih sedikit daripada penambahan pendapatan.

Berdasarkan hasil analisis aspek manajemen, usaha perkebunan rambutan layak diusahakan. Hal ini karena rencana kerja dan manajemennya dapat dilakukan dengan memperhatikan kondisi yang ada.

\section{Analisis Aspek Finansial}

Analisis finansial dilakukan dengan menggunakan kriteria-kriteria penilaian investasi yaitu Net Present Value (NPV), Internal Rate of Return (IRR), Net Benefit Cost Rasio (Net B/C), dan payback period.

\section{Biaya}

Biaya dalam usaha perkebunan rambutan dikelompokkan menjadi dua kelompok yaitu biaya investasi dan biaya operasional. Biaya investasi merupakan biaya yang dikeluarkan pada awal usaha perkebunan rambutan. Total biaya investasi usaha perkebunan rambutan adalah sebesar Rp 33.395.000,-.Rincian mengenai proyeksi biaya investasi perkebunan rambutan di Desa Jungkal Kecamatan Lampihong dapat dilihat pada tabel berikut.

Tabel 2. Proyeksi biaya investasi perkebunan rambutan di Desa Jungkal Kecamatan Lampihong

\begin{tabular}{lccc}
\hline \multicolumn{1}{c}{ Jenis } & Harga Satuan $(\mathrm{Rp})$ & Kebutuhan & Jumlah Nilai (Rp) \\
\hline Prainvestasi & 1.000 .000 & $1 \mathrm{Kali}$ & 1.000 .000 \\
Lahan & 30.000 .000 & $1 \mathrm{Ha}$ & 30.000 .000 \\
Bangunan dan Sumur & 1.500 .000 & $1 \mathrm{Unit}$ & 1.500 .000 \\
Sprayer & 225.000 & $1 \mathrm{Buah}$ & 225.000 \\
Cangkul & 40.000 & $2 \mathrm{Buah}$ & 80.000 \\
Parang & 35.000 & $2 \mathrm{Buah}$ & 70.000 \\
Gergaji & 40.000 & $1 \mathrm{Buah}$ & 40.000 \\
Senapan Angin & 450.000 & $1 \mathrm{Buah}$ & 450.000 \\
Ember & 15.000 & $2 \mathrm{Buah}$ & 30.000 \\
\hline \multicolumn{2}{c}{} & & 33.395 .000 \\
\hline
\end{tabular}

Biaya operasional adalah semua biaya yang harus dikeluarkan agar kegiatan bisnis dapat beroperasi atau berjalan secara normal. Total biaya operasional perkebunan rambutan sebesar Rp 241.305.000,-, dengan biaya rata-rata sebesar $\mathrm{Rp} 10.054 .375,-$ /tahun. Proyeksi total biaya perkebunan rambutan secara rinci dapat dilihat pada tabel berikut.

Tabel 3. Proyeksi total biaya perkebunan rambutan 


\begin{tabular}{cccc}
\hline $\begin{array}{c}\text { Tahun } \\
\text { Ke- }\end{array}$ & Biaya Investasi (Rp) & Biaya Operasional $(\mathrm{Rp})$ & $\begin{array}{c}\text { Total Biaya } \\
(\mathrm{Rp})\end{array}$ \\
\hline 1 & 33.395 .000 & 7.139 .000 & 40.534 .000 \\
2 & 0 & 2.178 .000 & 2.178 .000 \\
3 & 0 & 2.761 .000 & 2.761 .000 \\
4 & 0 & 3.311 .000 & 3.311 .000 \\
5 & 0 & 6.281 .000 & 6.281 .000 \\
6 & 0 & 6.900 .000 & 6.900 .000 \\
7 & 0 & 7.600 .000 & 7.600 .000 \\
8 & 0 & 8.360 .000 & 8.360 .000 \\
9 & 0 & 9.196 .000 & 9.196 .000 \\
10 & 0 & 10.115 .000 & 10.115 .000 \\
11 & 0 & 11.272 .000 & 11.272 .000 \\
12 & 0 & 12.399 .000 & 12.399 .000 \\
13 & 0 & 12.899 .000 & 12.899 .000 \\
14 & 0 & 13.399 .000 & 13.399 .000 \\
15 & 0 & 13.899 .000 & 13.899 .000 \\
16 & 0 & 14.399 .000 & 14.399 .000 \\
17 & 0 & 14.899 .000 & 14.899 .000 \\
18 & 0 & 15.399 .000 & 15.399 .000 \\
19 & 0 & 15.899 .000 & 15.899 .000 \\
20 & 0 & 15.000 .000 & 15.000 .000 \\
21 & 0 & 14.000 .000 & 14.000 .000 \\
22 & 0 & 10.000 .000 & 10.000 .000 \\
23 & 0 & 8.000 .000 & 8.000 .000 \\
24 & 0 & 6.000 .000 & 6.000 .000 \\
\hline Jumlah & 33.395 .000 & 241.305 .000 & 274.700 .000 \\
\hline Rata-Rata & 1.391 .458 & 10.054 .375 & 11.445 .833 \\
\hline
\end{tabular}

\section{Pendapatan}

Pendapatan usaha perkebunan rambutan diperoleh dari hasil penjualan buah rambutan dan pada tahun terakhir ditambah salvage value dari lahan perkebunan rambutan sebesar $\mathrm{Rp}$ 20.000.000,-. Dari hasil perhitungan diperoleh total pendapatan dari penjualan buah rambutan sebesar Rp 1.177.140.000,-. Total pendapatan usaha perkebunan rambutan jika ditambah salvage value menjadiRp 1.197.140.000,-.Proyeksi total pendapatan perkebunan rambutan secara rinci dapat dilihat pada tabel berikut 
Miranda Romully B.R. Sitanggang \& Norhalimah, Analisis kelayakan investasi...

Tabel 3. Proyeksi total pendapatan perkebunan rambutan

\begin{tabular}{cccc}
\hline Tahun Ke- & $\begin{array}{c}\text { Penjualan Buah Rambutan } \\
(\mathrm{Rp})\end{array}$ & $\begin{array}{c}\text { Selvage Value (Rp) } \\
\text { Jumlah } \\
(\mathrm{Rp})\end{array}$ & 0 \\
2 & 0 & 0 & 0 \\
3 & 0 & 0 & 1.500 .000 \\
4 & 1.500 .000 & 0 & 4.500 .000 \\
5 & 4.500 .000 & 0 & 9.000 .000 \\
6 & 9.000 .000 & 0 & 16.500 .000 \\
7 & 16.500 .000 & 0 & 24.000 .000 \\
8 & 24.000 .000 & 0 & 30.000 .000 \\
9 & 30.000 .000 & 0 & 59.400 .000 \\
10 & 59.400 .000 & 0 & 73.500 .000 \\
11 & 73.500 .000 & 0 & 74.880 .000 \\
12 & 74.880 .000 & 0 & 77.760 .000 \\
13 & 77.760 .000 & 0 & 79.800 .000 \\
14 & 79.800 .000 & 0 & 82.650 .000 \\
15 & 82.650 .000 & 0 & 81.000 .000 \\
16 & 81.000 .000 & 0 & 83.700 .000 \\
17 & 83.700 .000 & 0 & 89.100 .000 \\
18 & 89.100 .000 & 0 & 89.250 .000 \\
19 & 89.250 .000 & 0 & 81.600 .000 \\
20 & 81.600 .000 & 0 & 72.000 .000 \\
21 & 72.000 .000 & 0 & 60.000 .000 \\
22 & 60.000 .000 & 0 & 42.000 .000 \\
23 & 42.000 .000 & 0 & 27.000 .000 \\
24 & 27.000 .000 & 0 & 38.000 .000 \\
\hline Jumlah & 18.000 .000 & 20.000 .000 & 1.197 .140 .000 \\
\hline Rata-rata & 1.177 .140 .000 & 20.000 .000 & 49.880 .833 \\
\hline
\end{tabular}

\section{Net Present Value (NPV)}

Dari hasil perhitungan dengan menggunakan discount factor sebesar $13 \%$ diperoleh Net Present Value (NPV) positif sebesar Rp 134.646.379,-. Hasil ini menunjukkan bahwa usaha investasi perkebunan rambutan di Desa Jungkal Kecamatan Lampihong layak diusahakan.

\section{Internal Rate of Return}

Usaha perkebunan rambutan pada perhitungan dengan menggunakan tingkat suku bunga $30 \%$ diperoleh nilai NPV positif sebesar Rp 22.099,- dan pada tingkat suku bunga $31 \%$ diperoleh NPV negatif sebesar Rp 2.323.134,--

Nilai IRR yang dihasilkan lebih besar dari tingkat discount rate yaitu sebesar $30,01 \%$. Pada tingkat suku bunga 30,01\% ini NPV adalah sebesar nol (0).

\section{Net Benefit Cost Rasio (Net B/C)}

Dari hasi perhitungan dengan menggunakan discount factor $13 \%$ sesuai dengan tingkat suku bunga KUR BRI diperoleh net benefit positif sebesar Rp 173.096.805,- dan net benefit negatif sebesar Rp 38.450.426,-. Jadi nilai Net B/C sebesar 4,50. Ini menunjukkan Net $\mathrm{B} / \mathrm{C}>1$, berartiinvestasi menguntungkan/layak.

\section{Payback period}

Berdasarkan payback period suatu usaha investasi perkebunan rambutan adalah layak bila payback period lebih pendek daripada yang disyaratkan.Payback Period untuk usaha investasi perkebunan rambutan adalah selama 8 tahun 11 bulan 26 hari.

\section{Pembahasan}

\section{Analisis Aspek Non Finansial}


Analisis aspek-aspek non finansial digunakan untuk mengetahui sejauh mana rencana usaha investasi perkebunan rambutan layak atau tidak jika dilihat dari aspek non finansial. Dalam penelitian ini dapat dilihat dari aspek pasar, aspek teknis dan aspek manajemen.

\section{Aspek Pasar}

Analisis aspek pasar memegang peranan yang sangat penting sebelum memulai usaha perkebunan rambutan karena sumber pendapatan utama perkebunan rambutan adalah berasal dari penjualan buah rambutan yang dihasilkan. Apabila aspek pasar tidak diteliti secara benar bagaimana prospek di masa yang akan datang, bukan mustahil tujuan investasi tidak akan pernah tercapai untuk mendapatkan keuntungan. Bahkan bukan tidak mungkin usaha akan rugi.

Aspek pasar harus menganut falsafah bisnis "jangan menjual produk yang dapat kamu buat, tapi buatlah produk yang dapat kamu jual". Falsafah tersebut menunjukkan bahwa untuk memproduksi produk harus melihat potensi pasarnya terlebih dulu, tidak asal membuat produk, kemudian memasarkannya dengan berbagai upaya (Suliyanto, 2010).

Karena buah rambutan adalah produk yang musiman maka pada saat terjadi panen yang sama di berbagai daerah penawaran akan tinggi dan harga cenderung turun. Manajer atau pengusaha perkebunan rambutan harus pintar dalam menyelesaikan masalah ini, yaitu menjual hasil pekebunan ke daerah yang tidak terjadi waktu penen yang sama. Wilayah pemasaran yang biasa menjadi sasaran para pedagang buah adalah Kota Samarinda. Selain wilayah tersebut, pemasaran buah rambutan dapat menjalin kerjasama dengan industri makanan dan minuman, serta ekspor.

Tanaman rambutan asal Indonesia telah menembus pasar internasional, seperti Inggris, Belanda, perancis, Belgia, dan negara-negara di Asia Barat, serta Asia Tenggara. Buah rambutan sebagai buah tropis dalam perdagangan internasional sering dikelompokkan sebagai buah yang bersifat eksotik. Di negara-negara maju seperti Eropa, konsumsi rambutan meningkat, baik dalam bentuk buah segar maupun dalam bentuk buah olahan (Soedarya, 2009).

\section{Aspek Teknis}

Jika analisis pasar dan pemasaran menunjukkan sebuah usaha investasiperkebunan rambutan untuk dijalankan maka langkah berikutnya adalah menjawab pertanyaan apakah usaha perkebunan rambutan secara teknis dapat dijalankan atau tidak. Meskipun berdasarkan aspek pasar usaha investasi perkebunan rambutan layak dijalankan, tetapi jika secara teknis tidak dapat dijalankan dengan baik maka investasi sebaiknya ditolak.

Proses produksi dari hasil penelitian sedikit berbeda dengan pedoman teknis budidaya tanaman rambutan dikarenakan melihat kondisi lahan perkebunan dan input produksi yang ada di Desa Jungkal Kecamatan Lampihong. Untuk perkebunan rambutan di Desa Jungkal Kecamatan Lampihong pemupukan yang diberikan pada tanaman lebih sedikit dari pemupukan yang ada pada pedoman pedoman teknis budidaya tanaman rambutan. Hal ini karena berdasarkan fakta di lapangan walaupun tidak diberikan pemupukan tanaman masih dapat tumbuh baik. Pada budidaya tanaman rambutan juga tidak dilakukan kegiatan pegolahan bedengan. Selain berdasarkan fakta lapangan tanaman tetap tumbuh baik walaupun tanpa pembuatan bedengan juga berdasarkan pertimbangan untuk memperoleh keuntungan yang optimal. Jika pertambahan biaya produksi lebih tinggi dari pertambahan keuntungan maka pertambahan biaya ditekan sebisa mungkin.

\section{Aspek Manajemen}

Aspek manajemen mempunyai peranan penting, banyak proyek-proyek bisnis gagal dibangun maupun dioperasionalkan bukan disebabkan aspek lain, tetapi karena lemahnya manajemen. Didalam usaha perkebunan rambutan, telaah manajemennya antara lain menyusun rencana kerja, siapa saja yang terlibat, bagaimana mengkoordinasikan dan mengawasi pelaksanaan proyek dangan 
sebaik-baiknya. Sedangkan untuk telaah operasionalnya, antara lain menentukan secara efektif dan efesien mengenai produksi, jenis-jenis pekerjaan, dan pengadaan tenaga kerja yang dibutuhkan. Semakin baik manajemen dari perkebunan rambutan ini maka akan semakin baik hasil yang didapat dan dapat dipastikan perkebunan rambutan ini menjadi lebih layak.

\section{Analisis Aspek Finansial}

Aspek keuangan pada umumnya merupakan aspek yang paling akhir disusun dalam sebuah penyusunan analisis kelayakan bisnis. Hal ini karena kajian dalam aspek keuangan memerlukan informasi yang berkaitan dengan aspekaspek sebelumnya.

Banyak perusahaan yang menutup usahanya karena kesalahan dalam melakukan analisis keuangan. Kesalahan analisis keuangan dapat disebabkan karena salah dalam memproyeksikan pendapatan, biaya investasi, maupun kesalahan dalam memproyeksikan biaya operasional. Oleh karena itu, analisis aspek keuangan tidak dapat dipisahkan dari analisis aspek-aspek sebalumnya. Analisis aspek pasar, berkaitan dengan proyeksi penjualan/pendapatan. Analisis aspek teknis, berkaitan dengan biaya pembangunan, pengadaan peralatan, dan proses produksi. Analisis aspek manajemen, berkaitan dengan biaya perencanaan dan pembangunan perkebunan rambutan serta biaya operasional untuk membayar tenaga kerja yang diperlukan untuk menjalankan usaha.

\section{Net Present Value (NPV)}

Nilai bersih sekarang atau Net Present Value (NPV) dari suatu proyek merupakan nilai sekarang dari selisih antara benefit (pendapatan) dengan cost (biaya) pada discount rate tertentu. Perhitungan NPV perkebunan rambutan secara rinci dapat dilihat pada tabel berikut.

Tabel 4. Net Present Value (NPV) perkebunan rambutan dengan df $13 \%$

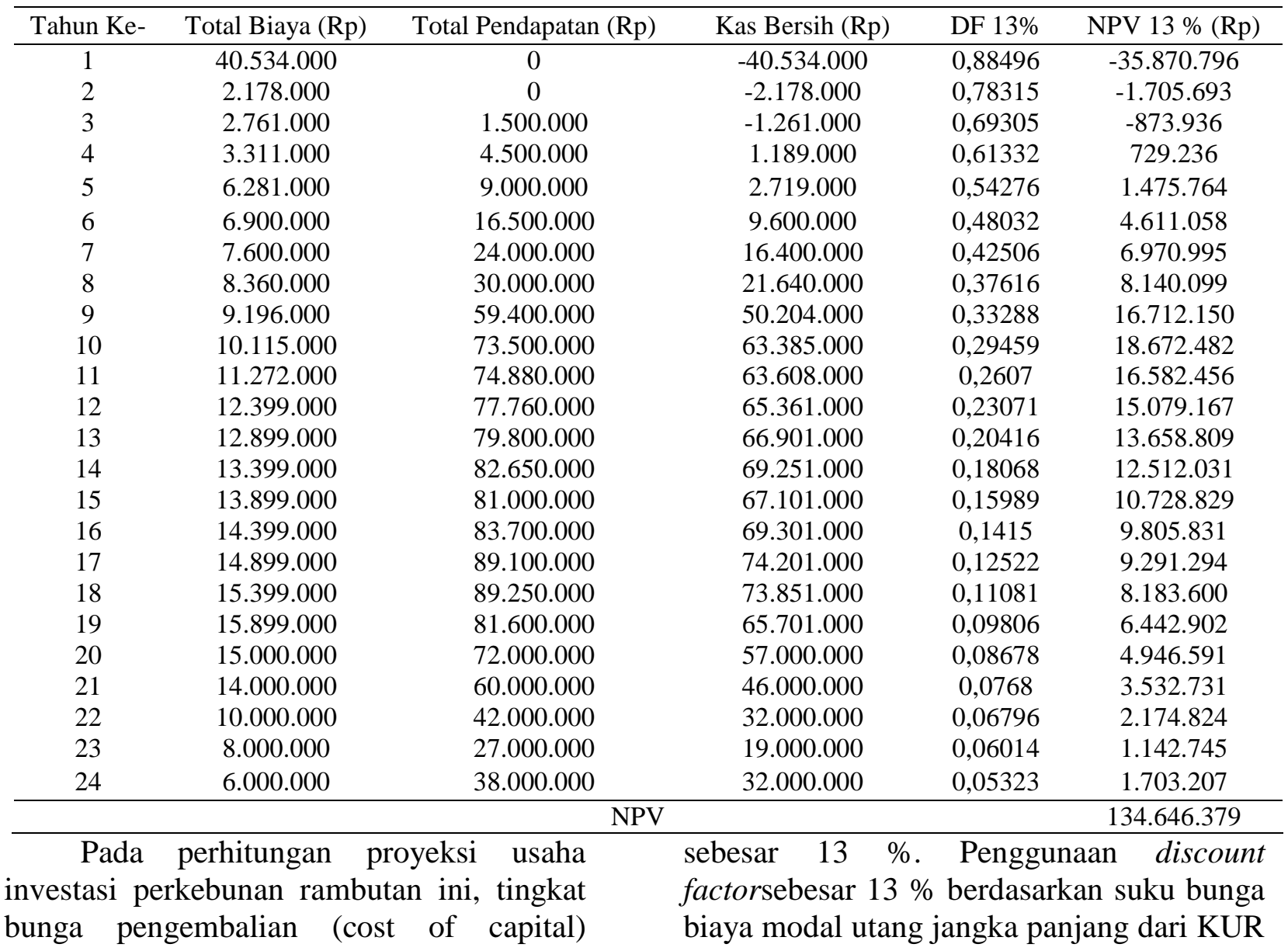


Ritel BRI saat ini. Dari hasil perhitungan dengan menggunakan discount factor sebesar $13 \%$ diperoleh Net Present Value (NPV) sebesar RP 134.646.379,-. Hasil ini menunjukkan bahwa NPV positif atau > 0 , ini berarati usaha investasi perkebunan rambutan di Desa Jungkal Kecamatan Lampihong layak diusahakan. Semakin besar NPV positif yang diperoleh maka akan semakin besar tingkat kelayakan usaha kebunan rambutan ini.

\section{Internal Rate of Return}

Internal Rate of Return adalah menghitung besarnya nilai tingkat suku bunga yang menyamakan nilai sekarang atas penerimaan kas bersih yang akandatang dari investasi perkebunan rambutan. Perhitungan NPV dengan df $30 \%$ dan $31 \%$ dapat dilihat pada

Tabel berikut.

Tabel 5. Perhitungan NPV dengan df $30 \%$ dan $31 \%$

\begin{tabular}{cccccc}
\hline $\begin{array}{c}\text { Tahun } \\
\text { ke- }\end{array}$ & $\begin{array}{c}\text { Kas Bersih } \\
(\mathrm{Rp})\end{array}$ & Df $30 \%$ & NPV 30\% (Rp) & Df 31\% & NVP 31 \% (Rp) \\
\hline 1 & -40.534 .000 & 0,7692 & -31.180 .000 & 0,7634 & -30.941 .985 \\
2 & -2.178 .000 & 0,5917 & -1.288 .757 & 0,5827 & -1.269 .157 \\
3 & -1.261 .000 & 0,4552 & -573.964 & 0,4448 & -560.920 \\
4 & 1.189 .000 & 0,3501 & 416.302 & 0,3396 & 403.735 \\
5 & 2.719 .000 & 0,2693 & 732.306 & 0,2592 & 704.779 \\
6 & 9.600 .000 & 0,2072 & 1.988 .892 & 0,1979 & 1.899 .518 \\
7 & 16.400 .000 & 0,1594 & 2.613 .608 & 0,151 & 2.477 .107 \\
8 & 21.640 .000 & 0,1226 & 2.652 .836 & 0,1153 & 2.495 .094 \\
9 & 50.204 .000 & 0,0943 & 4.734 .217 & 0,088 & 4.418 .722 \\
10 & 63.385 .000 & 0,0725 & 4.597 .831 & 0,0672 & 4.258 .666 \\
11 & 63.608 .000 & 0,0558 & 3.549 .236 & 0,0513 & 3.262 .327 \\
12 & 65.361 .000 & 0,0429 & 2.805 .424 & 0,0392 & 2.558 .958 \\
13 & 66.901 .000 & 0,033 & 2.208 .864 & 0,0299 & 1.999 .428 \\
14 & 69.251 .000 & 0,0254 & 1.758 .811 & 0,0228 & 1.579 .894 \\
15 & 67.101 .000 & 0,0195 & 1.310 .928 & 0,0174 & 1.168 .583 \\
16 & 69.301 .000 & 0,015 & 1.041 .468 & 00133 & 921.295 \\
17 & 74.201 .000 & 0,0116 & 857.774 & 0,0101 & 753.005 \\
18 & 73.851 .000 & 0,0089 & 656.714 & 0,0077 & 572.101 \\
19 & 65.701 .000 & 0,0068 & 449.416 & 0,0059 & 388.524 \\
20 & 57.000 .000 & 0,0053 & 299.922 & 0,0045 & 257.305 \\
21 & 46.000 .000 & 0,004 & 186.186 & 0,0034 & 158.511 \\
22 & 32.000 .000 & 0,0031 & 99.631 & 0,0026 & 84.175 \\
23 & 19.000 .000 & 0,0024 & 45.505 & 0,002 & 38.152 \\
24 & 32.000 .000 & 0,0018 & 58.953 & 0,0015 & 49.050 \\
\hline & & $\mathrm{NPV}$ df 30\% & 22.099 & $\mathrm{NPV}$ df $31 \%$ & -2.323 .134 \\
\hline
\end{tabular}

Nilai IRR yang dihasilkan lebih besar dari discount rate yaitu sebesar 30,01\%. Ini berarti usaha perkebunan rambutan di Desa Jungkal Kecamatan Lampihong layak diusahakan jika menggunakan modal dari KUR BRI dengan suku bunga $13 \%$ pertahun.

Pada tingkat suku bunga 30,01\% ini NPV adalah sebesar nol (0). Apabila usaha perkebunan rambutan menggunakan modal pinjaman dengan tingkat suku bunga hingga $30 \%$ masih layak dilaksanakan dengan NPV sebesar Rp 22.099,-, dan jika lebih dari $30,01 \%$ maka usaha perkebunan rambutan ini tidak layak.

\section{Net Benefit Cost Rasio (Net B/C)}

Dari hasil perhitungan dengan menggunakan 
discount factor $13 \%$ diperoleh Net $\mathrm{B} / \mathrm{C}$ sebesar 4,50. Ini menunjukkan Net $\mathrm{B} / \mathrm{C}>1$, berarti investasi perkebunan rambutan di Desa Jungkal Kecamatan Lampihong Kabupaten Balangan menguntungkan/layak. Semakin besar nilai Net B/C keuntungan juga akan semakin besar.

\section{Payback Period}

Berdasarkan payback period suatu usaha investasi perkebunan rambutan adalah layak bila payback period lebih pendek dari pada yang disyaratkan. Payback Perioduntuk usaha investasi perkebunan rambutan adalah selama 8 tahun 11 bulan 26 hari, ini artinya usaha perkebunan rambutan di Desa Jungkal Kecamatan Lampihong layak dilaksanakan. Jika perkebunan rambutan dapat dilakukan lebih baik lagi, maka payback period lebih cepat dari 8 tahun 11 bulan 26 hari dan sebaliknya jika perkebunan rambutan tidak dilakukan dengan baik payback period akan lebih lama.

\section{KESIMPULAN}

Kelayakan investasi usaha perkebunan rambutan di Desa Jungkal Kecamatan Lampihong Kabupaten Balangan jika dilihat dari aspek non finansial yaitu aspek pasar, aspek teknis, dan aspek manajemen diproyeksikan adalah layak dilakukan. Hal ini ditunjukkan pada potensi pasar yang cukup tinggi, lokasi usaha perkebunan yang menunjang keberhasilan usaha, dan rencana kerja dalam manajemennya dapat dilakukan dengan memperhatikan kondisi yang ada. Analisis kelayakan finansial menunjukkan bahwa investasi usaha perkebunan rambutan di Desa Jungkal adalah layak dilakukan. Hal ini ditunjukkan oleh hasil kriteria investasi Net Present Value (NPV) sebesar Rp 134.646.379,-, nilai Internal Rate of Return(IRR) yang dihasilkan lebih besar dari tingkat discount rate yaitu sebesar 30,01 \%, Net B/C sebesar 4,50, dan Payback Period selama 8 tahun 11 bulan 26 hari.

\section{DAFTAR PUSTAKA}

Ditjen Hortikultura. 2013. RKT Ditjen Hortikultura 2013. Jakarta.

Kasmir dan Jakfar. 2004. Studi Kelayakan Bisnis. Jakarta: Kencana

Soedaryo, Areif Prahasta. 2009. Agribisnis Rambutan. CV. Pustaka Grafitika. Bandung.

Suliyanto. 2010. Studi Kelayakan Bisnis. Andi. Yogyakarta. 